\title{
Enzymatic Extraction of Copper Complexes with Phenolic Compounds from Açaí (Euterpe oleracea Mart.) and Bilberry (Vaccinium myrtillus L.) Fruits
}

\author{
Justyna Wojcieszek ${ }^{1}$ • Lena Ruzik ${ }^{1}$
}

Received: 2 September 2015 / Accepted: 22 December 2015 /Published online: 7 January 2016

(C) The Author(s) 2016. This article is published with open access at Springerlink.com

\begin{abstract}
In this study, an analytical procedure for the extraction of phenolic copper complexes from two species of berries - Brazilian açaí (Euterpe oleracea Mart.) and Polish bilberry (Vaccinium myrtillus L.) - has been performed. Berries have proven to be a good source of vitamins and various nutrients, especially compounds with antioxidant capacity such as polyphenols, tocopherols, and ascorbic acid. Polyphenols from plant/foods interact strongly with cations (copper), and the experimental evidence presented in literature shows that the antioxidant activity is modified by the presence of metal ions. To obtain the information about phenolic copper complex attendance in berries, the enzymatic treatment with pectinase and hemicellulase was performed. These enzymes cause degradation of the cell wall matrix, causing enhancing to the extraction yield. Berries were treated with buffer (ammonium acetate) and enzymatic extraction (pectinase and hemicellulase) media and analyzed by size exclusion chromatography coupled to a mass spectrometer with inductively coupled plasma (SEC-ICP-MS) and an on-capillary liquid chromatograph coupled to an electrospray tandem mass spectrometer ( $\mu$-HPLC-ESI-MS/MS) techniques. The enzymatic treatment process significantly increases the extraction and helps extraction of other groups of copper complexes with polyphenols - such as those known from the literature and new one. In berries, copper is complexed by flavonols, for example, quercetin; flavanone, for example luteolin; and hydroxybenzoic acid, for example, syringic acid. We could indicate that in açaí and bilberry copper is complexed by non-cellwall phenols and, additionally, in bilberry by cell wall phenols.
\end{abstract}

Lena Ruzik

lenka@ch.pw.edu.pl

1 Faculty of Chemistry, Warsaw University of Technology, Noakowskiego 3, 00-664 Warsaw, Poland
The six copper complexes with polyphenol presence in berries are presented in the table of this work.

Keywords Açaí · Bilberry · Copper · Enzymatic treatment · HPLC $\cdot$ ICP-MS · ESI-MS/MS

\section{Introduction}

Berry fruits, such as bilberry (Vaccinium myrtillus L.), blackberry (Rubus fruticosus L.), blackcurrant (Ribes nigrum L.), blueberry (Vaccinium corymbosum L), and açaí (Euterpe oleracea Mart.), are a particularly rich source of antioxidants (Kalt et al. 1999; Kähkönen et al. 2001; Szajdek and Borowska 2008). Those compounds are mainly represented by vitamin $\mathrm{C}$ and polyphenols such as anthocyanins, phenolic acids, flavanols, flavonols, and tannins. They are known as natural antioxidants, and due to their high concentration and qualitative diversity, berry fruits are increasingly often referred to as natural functional foods (Wang and Lin 2000; Skupień and Oszmiański 2004).

Açaí (E. oleracea Mart.) is a tropical palm tree that occurs naturally in the Amazon region. Its spherical grape-sized fruits are green when they are young and then ripen usually to a dark purple (Strudwick and Sobel 1988; Heinrich et al. 2011). Its fruits, recently acclaimed as "super fruits," are especially rich in antioxidants like phenolic compounds and tocopherols (Rogez et al. 2011; Bichara and Rogez 2011). In acai, anthocyanins are the major phenolic compounds, and cyanidin 3-glucoside and cyanidin 3-rutinoside are in large concentrations (Dias et al. 2012; Smith et al. 2012), followed by flavonoids as orientin and homoorientin (Pacheco-Palencia et al. 2009). Other flavonoids belonging to the flavones, flavonols, flavanols, and dihydroflavanols are also present, as well as phenolic acids (Mulabagal and Calderón 2012; Dias et al. 2013). 
Bilberry (V. myrtillus L.), also known as the native European blueberry, is one of the richest sources of anthocyanins, which are responsible for the bluish red color of the bilberry fruit. These berries are thought to be related with many health benefits for humans, including eye protection, antioxidation, cardioprotection, antiinflammatory, hypoglycemic, and antimicrobial effects (Chu et al. 2011; Dinkova et al. 2014). They also contain a vast number of other phytochemicals for which there are no known deficiency conditions but which may have marked bioactivities in mammalian cells of potential health benefit (Tumbas Šaponjac et al. 2015; Beattie et al. 2005; Rouanet et al. 2010).

The main group of compounds in açaí and bilberry are phenolic compounds. Flavonoids (flavus-yellow), or bioflavonoids, are a ubiquitous group of polyphenolic substances which are present in most plants and concentrated in the seeds, fruit skin or peel, bark, and flowers (Middleton and Kandaswami 1994). More than 9000 different flavonoids have been identified to date, making them the largest group of plant chemicals. Due to their specific chemical structure, flavonoids easily chelate metal ions and create complex compounds (Malesev and Kunti 2007). The chelation of metals can be crucial in the prevention of radical formation, which damages target biomolecules. Moreover, the use of natural chelators such as flavonoids is better than the synthetic ones due to their toxic effects. In the structure of several flavonoids are three potential coordination sites between (a) 5hydroxy and 4-carbonyl group, (b) 3-hydroxy and 4-carbonyl group, and (c) 3', 4'-hydroxy group in B ring (Symonowicz and Kolanek 2012). These molecules interact strongly with cation, and the experimental evidence shows that the antioxidant activity is modified by the presence of metal ions. The observed free radical scavenging activity of flavonoid/metal ion mixtures is markedly increased for example when metal ion, copper, is complexed with quercetin (Domínguez et al. 2008).

The efficient extraction of phenolic compounds is highly expected to identify the copper phenolic complexes in fruits. It was shown that polysaccharides (cellulose, pectin, and glucomannan) were the most abundant components of fruits skins and anthocyanidins and condensed tannins are among the principal phenolic constituents (Arnous and Meyer 2008; Arnous and Meyer 2010). Microwave-assisted extraction (MAE) has been described in literature for extraction of phenolic compounds as an alternative to conventional techniques (solid-liquid extraction) (Hyun-Ku et al. 2012; Simsek et al. 2012; Brahim et al. 2014). In recent years, research into the application of enzymatic treatments in fruits matrices to release analytes has been increased. It has been shown that the application of enzymatic treatments in berries improves the attractiveness of dehydrated products (Meyer et al. 1998; Pawlak et al. 2012; Arvayo-Enriquez et al. 2013).

One of the solution to improve the extraction yield of the metal complexes was by breaking the cell walls of plants. The key to increase efficiency of the extraction of the metal complexes was to use this part of the plant. Cell wall is a nanocomposite material surrounding each cell outside the plasmalemma, which forms a continuous extracellular matrix and from cell to cell, the skeleton of plant tissues. It corresponds to an assembly of biopolymers, mainly polysaccharides but also proteins and phenolic compounds (Arnous 2009). Another reported mechanism of improving the extraction is the direct enzyme catalyzed breakage of the ether and/or ester linkages between the phenols and the plant cell wall polymers (Laroze et al. 2010).

Pectin is one of the most complex cell wall polysaccharides, mostly characterized by a high content in galacturonic acid (GalpA) (Shibuya and Nakane 1984). Pectinolytic enzymes are often used in industrial berry processing to support juice extraction. These enzymes cause degradation of the cell wall matrix, thus enhancing the extraction yield. Additionally, an increased extractability of phenolic compounds (particularly anthocyanins (Buchert et al. 2005) and flavonols (Kaponen et al. 2008)) has been observed in berry juices after enzyme-aided processing. Cellulose is a major component of cellulosic material in plants. It is crystalline via $\beta-1,4$ glycosidic linkages. Hemicellulose has relative weak crystal structure compared to cellulose and primarily consists of hetero- $\beta-1,4-D-x y l a n$ (Wada et al. 2008; Nishiyama et al. 2003).

Due to the importance of metal chelation for the characterization of antioxidant activities of compounds, we decided to study the chemical nature of the copper complexes with phenolic substances in berries by size exclusion chromatography coupled to a mass spectrometer with inductively coupled plasma (SEC-ICP-MS) and liquid chromatograph coupled to an electrospray mass spectrometer (HPLC-ESI-MS/MS). It was confirmed in numerous studies that flavonoids are chelating by metal ions (Malesev and Kunti 2007; Fernandez et al. 2002).

In our research, enzymatic extraction of copper complexes from bilberry and açaí fruits has been applied. To the best of our knowledge, there is no study in the literature about speciation analysis of metal complexes with phenolic compounds in berries after pectinase and hemicellulase treatment. The main novelty of the study was the application of $\mu$ RPLCESI-MS/MS to obtain the copper polyphenols complexes via enzymatic hydrolysis by hemicellulase and pectinase.

\section{Materials and Methods}

\section{Instrumentation}

Chromatographic separations were performed using Agilent 1100 gradient HPLC pump (Agilent Technologies, Waldbronn, Germany) as the sample delivery system. All connections were made of PEEK tubing $(0.17 \mathrm{~mm}$ i.d.). Agilent 7500a ICP Mass Spectrometer (Tokyo, Japan) was used as an element-specific detector for quantification of metal content in berries fruits (açaí and bilberry) and as on-line size exclusion LC detector. Ni-skimmer was installed, and position of sampler and nebulizer gas flow were adjusted daily with special emphasis to decrease the level of $\mathrm{CsO}^{+}$below $0.2 \%$ with the 
aim to minimize the risk of polyatomic interferences caused by oxides. Sample and standard solutions were prepared with addition of ${ }^{89} \mathrm{Y}$ as the internal standard.

The characterization of element species was examined by ESIMS/MS spectrometer Model 6460 Triple Quad LC/MS Jet Stream (Agilent Technologies, Wilmington, NC, USA) with a quadrupole mass analyzer. Coupled HPLC-ESI-MS/MS analysis was performed by capillary SB C18 column coupled to ESI-MS/MS.

A Bandelin Sonorex Model 1210 ultrasonic bath (Germany) and MPW Model 350R centrifuge (MPW Warsaw, Poland) were used for extraction procedures. Microwave digestion Speedwave ${ }^{\circledR}$ four Berghof (Germany) was used for mineralization.

Operational parameters for instruments are summarized in Table 1.

\section{Reagents}

All used reagents were graded as an analytical reagent and purchased from Sigma-Aldrich (Sigma-Aldrich, Buchs, Switzerland). Water (18 M $\Omega \mathrm{cm}$ ) prepared with a Milli-Q system (Millipore Elix 3, Millipore, Saint-Quentin, France) was used. The following commercial enzyme preparations were used: pectinase from Aspergillus niger, and hemicellulase from A. niger (Sigma-Aldrich, Buchs, Switzerland). The SEC column was calibrated using size exclusion standard (Bio-Rad, Warsaw, Poland).

\section{Sample Preparation}

Frozen bilberries (V. myrtillus L., harvested in Poland in 2012) were stored at $-20^{\circ} \mathrm{C}$ until analysis. The lyophilized Brazilian açaí berry (E. oleracea Mart.) was obtained from Kenay (imported from Brazil) and stored at $4{ }^{\circ} \mathrm{C}$ until analysis.

For the determination of total amount of elements, ground lyophilized fruits $(0.2 \mathrm{~g}$ dry mass after lyophilization) were digested by microwave-assisted mineralization with a mixture of $5 \mathrm{~mL}$ of $\mathrm{HNO}_{3}$ and $3 \mathrm{~mL}$ of $\mathrm{H}_{2} \mathrm{O}_{2}$. The mineralization method based on $\mathrm{HNO}_{3}$ with addition of $\mathrm{H}_{2} \mathrm{O}_{2}$ was chosen due to the higher oxidation potential of $\mathrm{H}_{2} \mathrm{O}_{2}$. The presence of elements during ICP-MS analysis is favorable as is stable in acidic solutions of $\mathrm{HNO}_{3}$ which is most commonly used to prepare samples and to wash the apparatus. After cooling down, the digest was diluted to final volume of $10 \mathrm{~mL}$ with Milli-Q water and further diluted in $2 \% \mathrm{HNO}_{3}$ before ICP-MS analysis (Fig. 1).

\section{Extraction Procedure of Copper Species from Berries Fruits}

The berry samples were extracted with portions of sonicated $10 \mathrm{mM}$ ammonium acetate (pH 5.5 dedicated to flavonoids and other small bioligands suspected to reveal ability to bind copper). Homogenized samples $(0.05 \mathrm{~g})$ were extracted with $2.0 \mathrm{~mL}$ of ammonium acetate during $1 \mathrm{~h}$ in ultrasonic bath (Model 1210, Walldorf, Germany) (Rybak and Ruzik 2013). The obtained solutions were centrifuged for $20 \mathrm{~min}$ at $10,000 \mathrm{rpm}$ at $21^{\circ} \mathrm{C}$. The final supernatant was filtered with $0.45 \mu \mathrm{m}$ syringe filter (Sigma-Aldrich, Bellefonte, PA, USA); two first drops were discarded and only the remaining part of the filtrate was injected on the size exclusion column. Pre-concentration of samples by lyophilization was optional toward SEC-ICP-MS analysis.

\section{Enzymatic Hydrolysis Procedure of Copper Species from Berries Fruits}

Pectinase (a pectinolytic enzyme) and hemicellulase (a hemicellulotytic enzyme) were selected for hydrolysis of cellulose and hemicellulose in food processing. Enzymatic hydrolysis of lyophilized berries was carried out in thermostatically controlled water bath (Memmert, Germany) in accordance with the reaction time of $2 \mathrm{~h}$ and temperature of $50^{\circ} \mathrm{C}$. A sample of $0.05 \mathrm{~g}$ lyophilized berries was hydrolyzed in $2.5-\mathrm{mL}$ acetate buffer $(10 \mathrm{mM})$, $\mathrm{pH} 6.8$, and the relevant enzyme specimen was added at the enzyme/substrate ratio $5 \%$ (hemicellulase) or $7 \%$ (pectinase) volume/weight $(\mathrm{E} / \mathrm{S} \%)$ calculated on dry matter base. The sample was mixed in ultrasonic bath for $15 \mathrm{~min}$ and incubated in the thermostatic water bath. Following centrifugation at 10,000 rpm for $20 \mathrm{~min}$ at $21^{\circ} \mathrm{C}$. The final supernatant was decanted into a 1$\mathrm{mL}$ vial and kept under at $4{ }^{\circ} \mathrm{C}$ until the time of analyses.

After the enzymatic extraction, the extracts were cleaned up (Pawlak et al. 2012). The samples were ultrafiltrated using $10-\mathrm{kDa}$ cutoff filters for separation of low molecular weight (LMW) compounds from enzymes (Howlett et al. 2006).

\section{Results and Discussion}

\section{Total Content of Metals and Preliminary SEC-ICP-MS Profiling of Extract Containing Copper Complexes}

The efficiency of the extraction of copper ions from açaí with enzymes was better than from ammonium acetate; however, the differences in extraction yield of bilberry were less significant (Table 2).

Size exclusion LC using dextran covalently bound to porous agarose drops has been previously shown to help the speciation analysis of labile coordination complexes, causing only minor dissolution of the species of interest (Karasiński et al. 2014; Persson et al. 2009; Vacchina et al. 1999). In the initial SEC-ICP-MS speciation analysis of copper complexes in berries, we have optimized the temperature, time, and concentration of pectinase and hemicellulase treatment on dried berry fruit. The optimal extraction conditions included vortexing during $2 \mathrm{~h}$ in $50^{\circ} \mathrm{C}$, using $7 \%$ of pectinase and $5 \%$ hemicellulose as an extractant.

Thus, an enzymatic extracts of berries was analyzed by SEC-ICP-MS, and obtained chromatograms are shown in Fig. 2. The chromatogram of the ammonium acetate, 
Table 1 Operational parameters for HPLC, ICP-MS, and ESI-MS/ MS

\begin{tabular}{|c|c|c|}
\hline \multicolumn{3}{|l|}{ Settings } \\
\hline ICP-MS & \multicolumn{2}{|l|}{ Agilent 7500a } \\
\hline RF power & \multicolumn{2}{|l|}{$1350 \mathrm{~W}$} \\
\hline Plasma, auxiliary and nebulizer gas flow & \multicolumn{2}{|c|}{$15.0,1.0$, and $1.05 \mathrm{~L} \mathrm{~min}^{-1}$} \\
\hline Cones & \multicolumn{2}{|c|}{ Sampler, Ni; Skimmer, Ni } \\
\hline Monitored isotopes & \multicolumn{2}{|l|}{${ }^{63} \mathrm{Cu},{ }^{65} \mathrm{Cu}$} \\
\hline Dwell time & \multicolumn{2}{|l|}{$0.1 \mathrm{~ms}$} \\
\hline \multicolumn{3}{|l|}{ HPLC separation } \\
\hline pump & \multicolumn{2}{|l|}{ Agilent 1100} \\
\hline Column & \multicolumn{2}{|c|}{$\begin{array}{l}\text { Superdex } 200(10 \times 300 \mathrm{~mm} \times 10 \mu \mathrm{m}) \text {, GE Healthcare Life } \\
\text { Sciences }\end{array}$} \\
\hline Mobile phase & \multicolumn{2}{|c|}{$10 \mathrm{mM}$ ammonium acetate buffer ( $\mathrm{pH} 7.4)$} \\
\hline elution program & \multicolumn{2}{|l|}{ Isocratic } \\
\hline Flow & \multicolumn{2}{|l|}{$0.7 \mathrm{~mL} \mathrm{~min}^{-1}$} \\
\hline Injection volume & \multicolumn{2}{|l|}{$100 \mu \mathrm{L}$} \\
\hline Column temperature & \multicolumn{2}{|l|}{$24^{\circ} \mathrm{C}$} \\
\hline Pump & \multicolumn{2}{|l|}{ Agilent 1200 Series } \\
\hline Column & \multicolumn{2}{|c|}{ Zorbax SB C18 $(3.5 \mu \mathrm{g} 0.3 \times 150 \mathrm{~mm})$} \\
\hline Injection volume $(\mu \mathrm{L})$ & \multicolumn{2}{|l|}{0.1} \\
\hline Flow rate $\left(\mu \mathrm{L} \min ^{-1}\right)$ & \multicolumn{2}{|l|}{5} \\
\hline Eluents & \multicolumn{2}{|c|}{$\begin{array}{l}\text { A: mixture water-methanol }(95: 5 v / v) \text { with } 0.1 \% \text { formic acid } \\
\text { B: mixture methanol-water }(95: 5 v / v)\end{array}$} \\
\hline \multirow[t]{5}{*}{ Gradient program } & Time, min & $\% \mathrm{~B}$ \\
\hline & 0 & 0 \\
\hline & 8 & 0 \\
\hline & 23 & 90 \\
\hline & 35 & 90 \\
\hline \multicolumn{3}{|l|}{ ESI-MS/MS detection } \\
\hline Detector & \multicolumn{2}{|c|}{ Agilent 6460 Triple Quad LC/MS with JetStream technology } \\
\hline Polarity & \multicolumn{2}{|l|}{ Positive, negative } \\
\hline Mode & \multicolumn{2}{|l|}{ SCAN, PI } \\
\hline Ionization voltage $(\mathrm{V})$ & \multicolumn{2}{|l|}{$2500(\mathrm{PI}), 1500(\mathrm{NI})$} \\
\hline Nebulizer pressure (psi) & \multicolumn{2}{|l|}{55} \\
\hline Gas temperature $\left({ }^{\circ} \mathrm{C}\right)$ & \multicolumn{2}{|l|}{300} \\
\hline Gas flow $\left(\mathrm{L} \min ^{-1}\right)$ & \multicolumn{2}{|l|}{8} \\
\hline Sheath gas flow $\left(\mathrm{L} \min ^{-1}\right)$ & 6 & \\
\hline Sheath gas temperature $\left({ }^{\circ} \mathrm{C}\right)$ & 300 & \\
\hline Mass range $(m / z)$ & $50-600$ & \\
\hline Collision energy (V) & $5-30$ & \\
\hline
\end{tabular}

pectinase, and hemicellulase extracts contains one intensive peak at $27 \mathrm{~min}$; during the time of extraction (check 1, 2, 6, and $24 \mathrm{~h}$ ), the intensity and profile of the chromatograms have not changed. During the long treatment of enzyme (24-72 h), the intensity of peak decreased.

Subsequent to enzymatic treatment of pectinase on bilberry fruit (after $2 \mathrm{~h}$ of extraction), we could observe two other peaks after $22 \min (44 \mathrm{kDa})$ and $33 \mathrm{~min}(1.35 \mathrm{kDa})$. During the long extractions, the peak at 22 min could not be observed at the obtained chromatogram. The pectinase degraded the cell wall matrix and increased extractability of phenolic compounds, particularly anthocyanins and flavonols. It could indicate that enzymatic treatment increases extractability of the new copper complexes with 

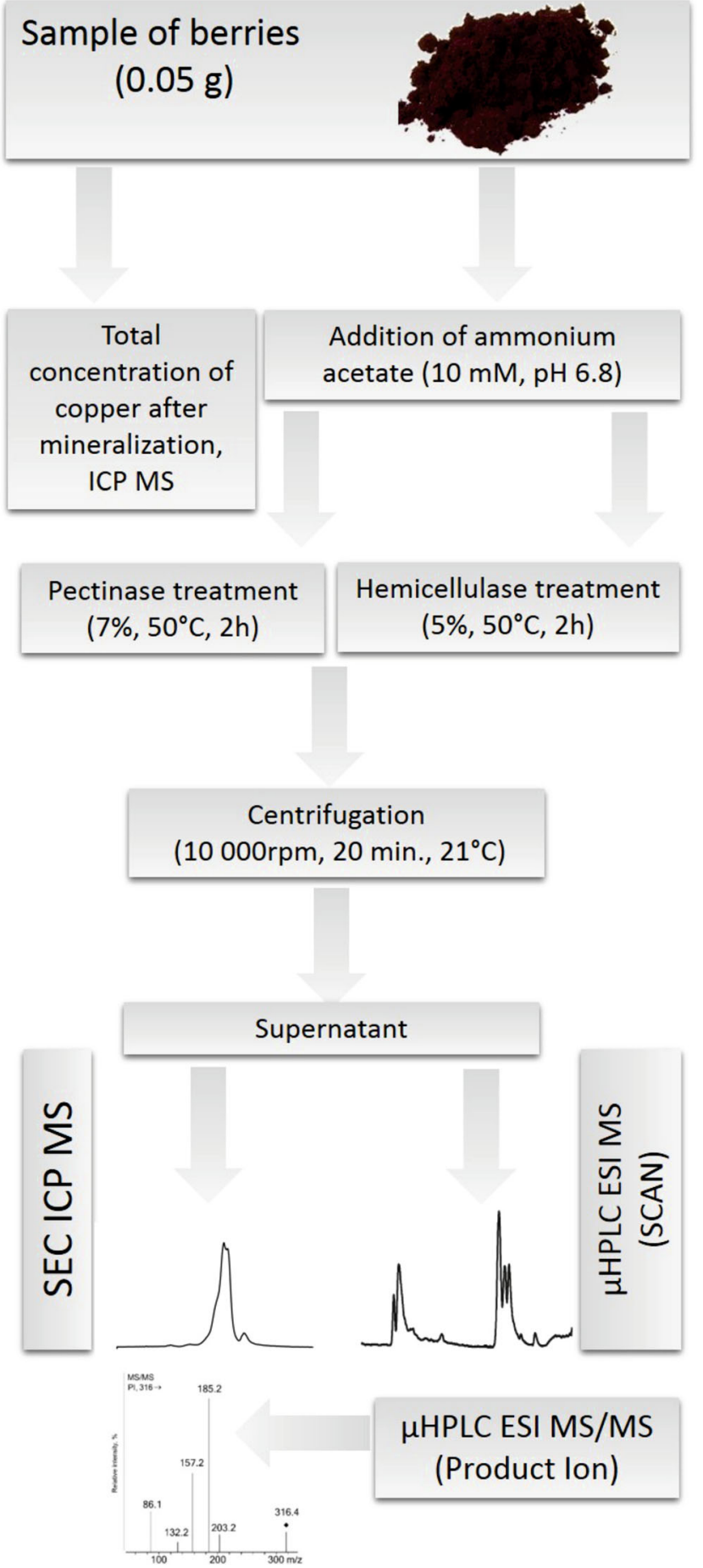

Fig. 1 Diagram of the enzymatic treatment of berries enhancing extractability of copper complexes

bioligands from cell wall. The hemicellulase treatment degraded the $\beta(1,4)$-linkages from the non-reducing end of the chain of cellulose and xylans - the polysaccharides in fruits.

Additionally, following the pectinase treatment on açaí fruits, we could not observe the peak after 22 min-it could indicate that copper complexes in açaí fruits are present only in plant vacuoles and the cell wall does not play a major role in
Table 2 Efficiency of copper ions extraction with different medium from açaí berry and bilberry

\begin{tabular}{lll}
\hline After extraction & Açaí (\%) & Bilberry (\%) \\
\hline 10 mM ammonium acetate & $59.55 \pm 0.39$ & $35.52 \pm 0.16$ \\
Pectinase & $71.70 \pm 0.62$ & $20.42 \pm 0.17$ \\
Hemicellulase & $67.47 \pm 1.80$ & $45.75 \pm 0.83$ \\
\hline
\end{tabular}

accumulation of the copper complexes with bioligands - different mechanism than in bilberry fruits.

Phenols occurring in plants are not always coupled with the plant cell walls. In literature, it was demonstrated that phenols can also be found within the cell cytoplasm, inside the cellular vacuoles or even in, or very near, the cell nucleus (Pinelo et al. 2006; Conn et al. 2003) - the same like in açaí fruits. We could indicate that in açaí and bilberry, copper is complexed by non-cell-wall phenols and, additionally, in bilberry by cell wall phenols.
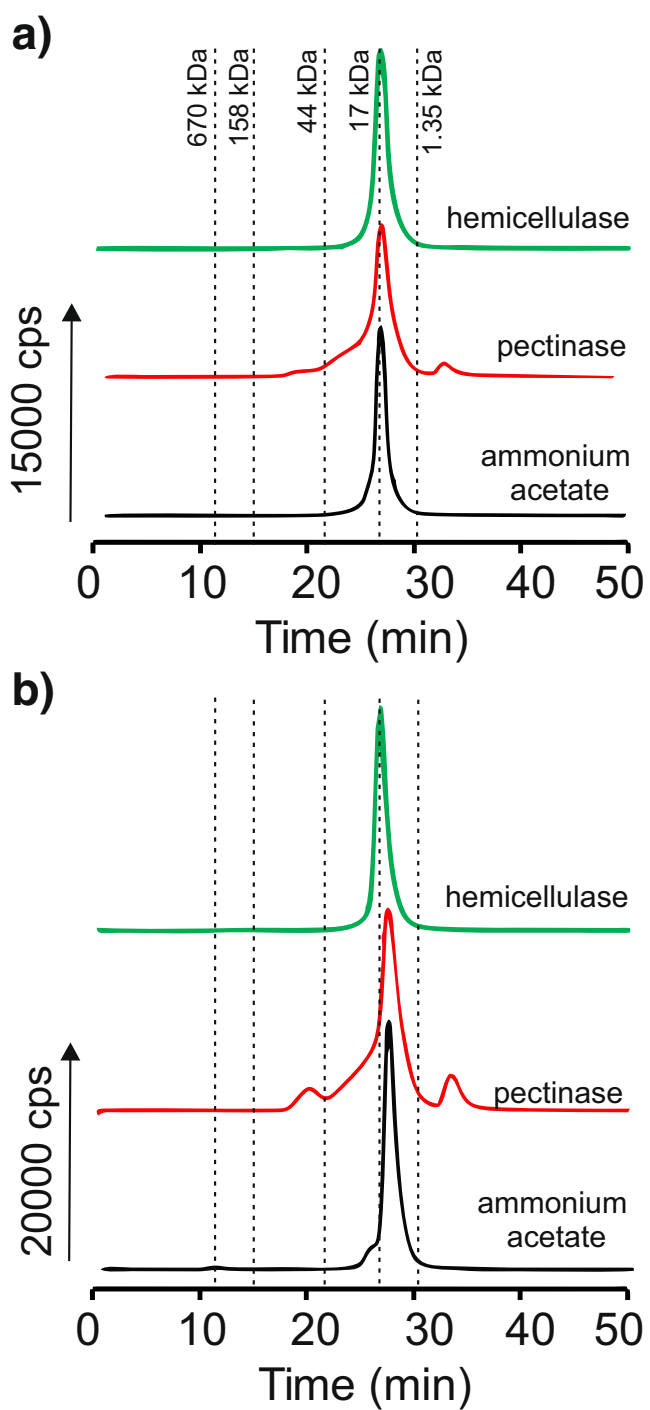

Fig. 2 SEC-ICP-MS chromatograms of $\mathbf{a}$ açaí and $\mathbf{b}$ bilberry fruit extracts 


\section{Identification of Copper Species in Berry Fruits by $\mu$-HPLC-ESI-MS/MS}

The next step of the investigation was to analyze açaí and bilberry fruit extracts by using capillary $\mu$-HPLC-ESI-MS/ MS. The obtained chromatograms with different peaks were shown on Fig. 3. Extracted ion chromatograms for the identified compounds (Table 3) are shown on Fig. 4.

On the chromatograms after enzymatic treatment of berry fruits, we could observe a similar group of peaks: from hydrophilic compounds at retention time of about 4-10 $\mathrm{min}$ in all extracts (ammonium acetate, enzymes), from 10 to $14 \mathrm{~min}$ in enzymatic extracts and next hydrophobic compounds with retention time 20-27 min for enzymes extracts (hemicellulase and pectinase), and 27-40 min after ammonium acetate and enzymatic extraction. Additionally, in the first group of polar compounds in ammonium acetate extract of açaí fruit, we could observe one new peak at retention time of $7 \mathrm{~min}$. The intensity of peaks at $\operatorname{tr}=4 \mathrm{~min}$ and $\operatorname{tr}=5 \mathrm{~min}$ are different in presented extracts. In açaí and bilberry fruit extracts (pectinase and hemicellulase), we could observe a new group of compounds on chromatogram after 10-24 min of elution. Also, on chromatograms obtained after pectinase extraction on berries fruits, we could observe a new group of compounds at 34-36 min. It should be pointed out that certain phenolic acids are most likely to show high concentration in the pectin (Fry 1982; Ishii 1994). In our studies after the pectinase treatment, we could observe new peaks on the chromatograms, with long retention times indicated on the new extracted copper compounds. A part of the polyphenols in fruits skins has also been proposed to bound with the cell wall polysaccharides by glycosidic bonds (Joutei et al. 1994), and probably after pectinase treatment, they were present in extract.

After examination of the mass spectra, signals with specific isotopic profile were found in all extracts. The profile of the peak in the spectrum is important in order to know how many copper ions are bound to each phenolic group. In this deference, we compared among them the isotopic profiles of most visible peaks in the ESI-MS/MS spectra obtained in the SCAN mode. These were only single charged ions corresponding to complexes with one copper. The most abundant
Fig. $3 \mu$-HPLC ESI MS chromatograms of a açaí (Euterpe oleracea Mart.) and b bilberry (Vaccinium myrtillus L.), after extraction registered at positive ion SCAN mode (red, pectinase; green, hemicellulase; black, ammonium acetate) (color figure online)

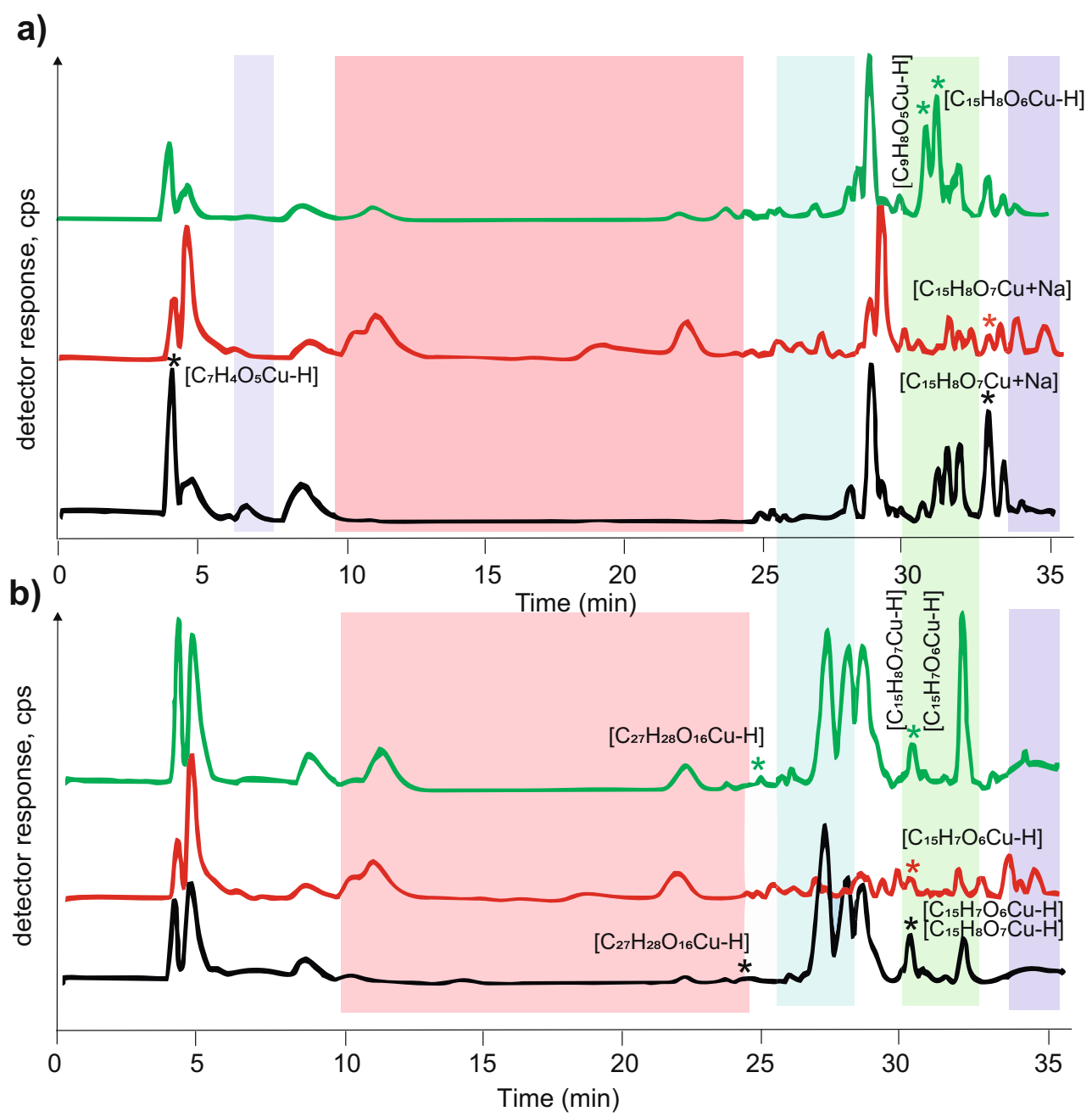


Table 3 Copper complexes observed in $\mu$-HPLC-ESI-MS/MS spectra of açaí berry and bilberry

\begin{tabular}{|c|c|c|c|c|c|c|c|}
\hline & & $t_{\mathrm{r}}(\min )$ & $\begin{array}{l}\text { Molecular } \\
\text { formula }\end{array}$ & Ligand & $\begin{array}{l}{[\mathrm{M}+\mathrm{H}]^{+}} \\
m / z\end{array}$ & $\begin{array}{l}{[\mathrm{M}-\mathrm{H}]^{-}} \\
m / z\end{array}$ & MS/MS \\
\hline \multirow[t]{8}{*}{ Açaí } & Ammonium acetate & 4.4 & {$\left[\mathrm{C}_{7} \mathrm{H}_{4} \mathrm{O}_{5} \mathrm{Cu}-\mathrm{H}\right]$} & Gallic acid & & 231 & $117\left[\mathrm{C}_{8} \mathrm{H}_{5} \mathrm{O}\right], 145$ \\
\hline & & 33.57 & {$\left[\mathrm{C}_{15} \mathrm{H}_{8} \mathrm{O}_{7} \mathrm{Cu}+\mathrm{Na}\right]$} & Quercetin & 387 & & $151\left[\mathrm{C}_{7} \mathrm{H}_{3} \mathrm{O}_{4}\right], 231^{\mathrm{a}}\left(151+\mathrm{H}_{2} \mathrm{O}\right) \mathrm{Cu}$ \\
\hline & & 34.7 & & Unknown & 415 & & $171^{\mathrm{a}}\left[\mathrm{C}_{6} \mathrm{H}_{4} \mathrm{O}_{2} \mathrm{Cu}\right]$ \\
\hline & Pectinase & 31.7 & & Unknown & 399 & & $286\left[\mathrm{C}_{15} \mathrm{H}_{10} \mathrm{O}_{6}\right]$ \\
\hline & & 33.52 & {$\left[\mathrm{C}_{15} \mathrm{H}_{8} \mathrm{O}_{7} \mathrm{Cu}+\mathrm{Na}\right]$} & Quercetin & 387 & & $151\left[\mathrm{C}_{7} \mathrm{H}_{3} \mathrm{O}_{4}\right]$ \\
\hline & Hemicellulase & 31.66 & {$\left[\mathrm{C}_{9} \mathrm{H}_{8} \mathrm{O}_{5} \mathrm{Cu}-\mathrm{H}\right]$} & Syringic acid & & 259 & $171^{\mathrm{a}}\left[\mathrm{C}_{6} \mathrm{H}_{4} \mathrm{O}_{2} \mathrm{Cu}\right]$ \\
\hline & & 33.12 & {$\left[\mathrm{C}_{15} \mathrm{H}_{8} \mathrm{O}_{6} \mathrm{Cu}-\mathrm{H}\right]$} & Kaempherol & & 347 & $173\left[\mathrm{C}_{7} \mathrm{H}_{3} \mathrm{O}_{4}\right] \mathrm{Na}$ \\
\hline & & 34.7 & & Unknown & 415 & & $171^{\mathrm{a}}\left[\mathrm{C}_{6} \mathrm{H}_{4} \mathrm{O}_{2} \mathrm{Cu}\right]$ \\
\hline \multirow[t]{5}{*}{ Bilberry } & $\begin{array}{l}\text { Ammonium acetate/ } \\
\text { hemicellulase }\end{array}$ & 24.7 & {$\left[\mathrm{C}_{27} \mathrm{H}_{28} \mathrm{O}_{16} \mathrm{Cu}-\mathrm{H}\right]$} & Peonidine 3-rutinoside & & 671 & $401^{\mathrm{a}}\left[\mathrm{C}_{22} \mathrm{H}_{23} \mathrm{O}_{11} \mathrm{Cu}+3 \mathrm{H}_{2} \mathrm{O}\right]$ \\
\hline & & 25.3 & & Unknow & 467 & & $137\left[\mathrm{C}_{8} \mathrm{H}_{9} \mathrm{O}_{2}\right]$ \\
\hline & & 30.2 & {$\left[\mathrm{C}_{15} \mathrm{H}_{7} \mathrm{O}_{6} \mathrm{Cu}-\mathrm{H}\right]$} & Luteolin & & 347 & $285\left[\mathrm{C}_{15} \mathrm{H}_{10} \mathrm{O}_{6}\right]$ \\
\hline & & 30.6 & {$\left[\mathrm{C}_{15} \mathrm{H}_{8} \mathrm{O}_{7} \mathrm{Cu}-\mathrm{H}\right]$} & Quercetin & & 363 & $151\left[\mathrm{C}_{7} \mathrm{H}_{3} \mathrm{O}_{4}\right], 231^{\mathrm{a}}\left(151+\mathrm{H}_{2} \mathrm{O}\right) \mathrm{Cu}$ \\
\hline & Pectinase & 30.2 & {$\left[\mathrm{C}_{15} \mathrm{H}_{7} \mathrm{O}_{6} \mathrm{Cu}-\mathrm{H}\right]$} & Luteolin & & 347 & $285\left[\mathrm{C}_{15} \mathrm{H}_{10} \mathrm{O}_{6}\right]$ \\
\hline
\end{tabular}

${ }^{\mathrm{a}}$ The signal corresponds to molecules containing metal

MS signals with characteristic isotopic profile were attributed to the potential quasi-molecular ions and analyzed in product ion mode. The obtained MS/MS spectra (Fig. 5) of copper complexes allowed identification of lost fragments and, in consequence, propose their structures (Table 3).

In bilberry fruits, copper has been complexed by flavonols (quercetin) and flavanone-luteolin. Also, we could indicate that hemicellulase and ammonium acetate extracted the same kind of copper complexes and the similar group of flavonoids (Fig. 4). The first mass spectra were obtained at $24.7 \mathrm{~min}$ for parent ions $\mathrm{m} / z 671$ and 673 and correspond with copper complex with quercetin rutinoside. The most characteristic value $\mathrm{m} / \mathrm{z} 401$ corresponds to the residue of quercetin $\left(323+\mathrm{H}_{2} \mathrm{O}\right)$ bound to copper. The next fragmentation was carried out for parent ions at $\mathrm{m} / \mathrm{z} 347$ and 349 at $30.2 \mathrm{~min}$, which corresponds with luteolin copper complex. The most important signal was obtained at $\mathrm{m} / \mathrm{z} 285$ corresponding to luteolin after loss of copper from complex. In the case of parent ions at $\mathrm{m} / \mathrm{z} 363$ and 365 fragmented at $30.6 \mathrm{~min}$ the copper complex with quercetin - the most specific signals were obtained at $m / z 231$ which corresponded to copper bound to residue of quercetin $\left(151+\mathrm{H}_{2} \mathrm{O}\right)$ (Dias et al. 2013).

In açaí berry extracts, we could identify copper complexes with hydroxybenzoic acids (HBA) and flavonols.
Fig. $4 \mu$-HPLC-ESI-MS/MS extracted ion chromatograms of identified compounds in berry extracts registered in SCAN mode (see Table 3 for details)

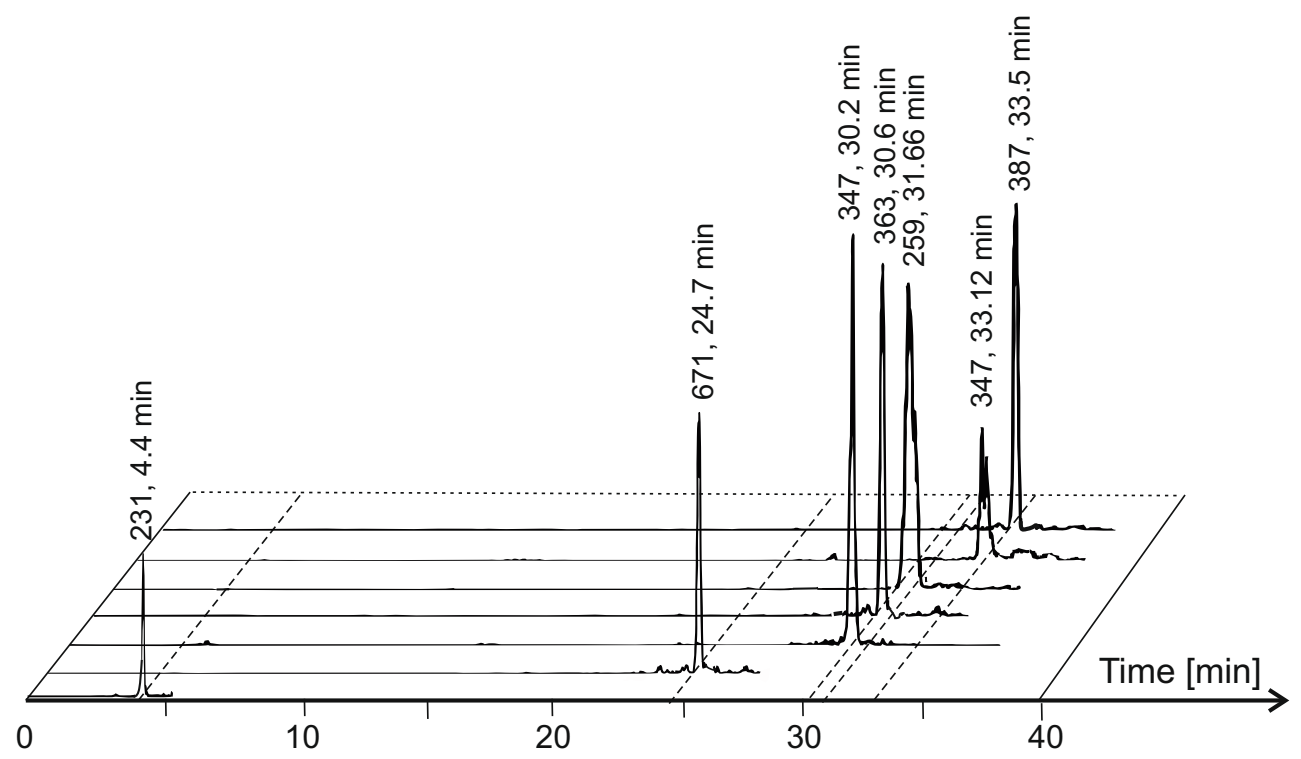


a)

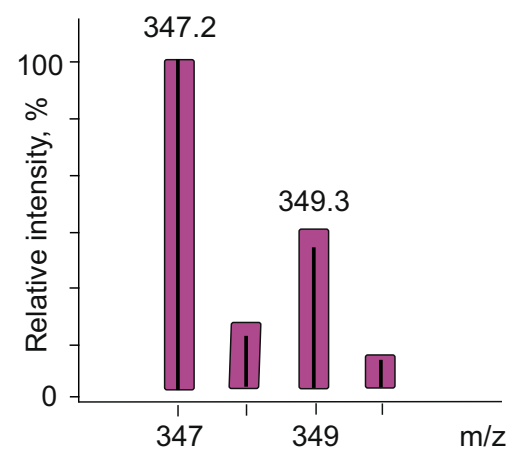

b) $\mathrm{PI}, 347 \rightarrow$

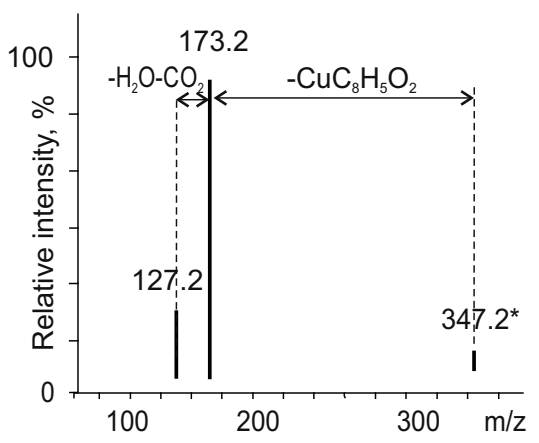

c) EIC $347, \mathrm{~T}: 347 \rightarrow 173$

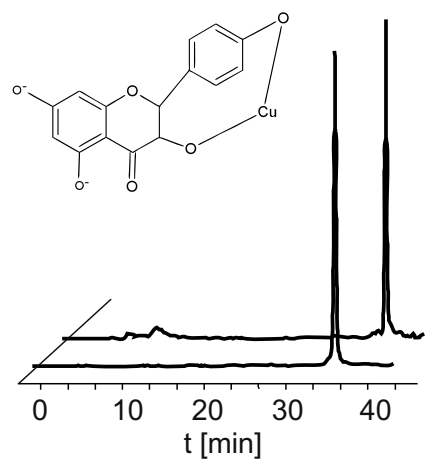

Fig. 5 The mass spectra obtained by $\mu$-HPLC-ESI-MS/MS in negative ion mode: a theoretical (bars) and experimental isotopic profile (lines) in SCAN mode for $m / z$ 347.2. b The product ion (PI) mass spectra obtained for $\mathrm{t} \mathrm{m} / \mathrm{z} 374.2$ and $\mathbf{c}$ extracted ion chromatography at $30.2 \mathrm{~min}$ in the $\mathrm{SCAN}$ mode for $m / z 347 \rightarrow 173$
After the hemicellulase treatment, we could observe the new complex with syringic acid and kaempherol. The first mass spectra were obtained at $4.4 \mathrm{~min}$ for parent ions $\mathrm{m} / \mathrm{z} 231$ and 233 - indicating that the copper complex with gallic acid and the most characteristic value $\mathrm{m} / \mathrm{z} 117$ corresponds to the residue of flavonoid ring $\mathrm{C}_{8} \mathrm{H}_{5} \mathrm{O}$. The next fragmentation was carried out for parent ions at $\mathrm{m} / \mathrm{z} 259$ and 261 at $31.61 \mathrm{~min}$ - the copper complex with next hydroxybenzoic acid, syringic acid. The most important signal was obtained at $m / z 171$ which corresponded to copper bound to A ring of the skeleton of flavonoids and molecular mass indicated to syringic acid. In the case of parent ions at $\mathrm{m} / \mathrm{z} 347$ and 349 responsible for copper complex with kaempherol fragmented at $33.12 \mathrm{~min}$. The most specific signals were obtained at $\mathrm{m} / \mathrm{z}$ 173 which corresponded to sodium adduct $\left[\mathrm{C}_{7} \mathrm{H}_{3} \mathrm{O}_{4}\right]$. And, the last one, mass spectra were obtained at $33.57 \mathrm{~min}$ for parent ions at $m / z 387$ and 389-the sodium adduct of copper complex with quercetin. The most specific signals were obtained at $m / z 151$ which corresponded to quercetin residue (Dias et al. 2013).

Additionally, we could also observe the new copper complexes (compared with theoretical isotopic profiles of copper complexes) at $m / z 467$ and 465 at 25.31 min with the most specific signals at $\mathrm{m} / \mathrm{z} 137$ which corresponding to the B ring of skeleton of flavonoids. The next parent ions at $\mathrm{m} / \mathrm{z} 399$ and 401 were observed at $31.71 \mathrm{~min}$, with the specific signal at $\mathrm{m} / \mathrm{z} 286$ corresponding to the skeleton of flavonoids. In the case of parent ions at $\mathrm{m} / \mathrm{z} 415$ and 417 fragmented at $34.74 \mathrm{~min}$, the most specific signals were obtained at $\mathrm{m} / \mathrm{z}$ 171 which corresponded to copper bound to A ring of the skeleton of flavonoids (Sun et al. 2007).

The presented study demonstrated that phenolic compounds through different subclasses were able to chelate copper ions in plant fruits, though, in a variable way. The chelating sites for copper do not significantly differ from those of iron and other metals (Ríha et al. 2014; Mladenka et al. 2011).

The flavonols and phenolic acids have been suggested to be integrated in the fruit skin with cell wall polysaccharides via hydrophobic interactions and/or hydrogen bonds (Meyer et al. 1998; Pinelo et al. 2006), and the anthocyanin may be bound in insoluble phenol-protein-polysaccharide complexes (Markham et al. 2000). After the enzymatic treatment (pectinase and hemicellulase), the copper complexes with those compounds unbounded from the cell wall polysaccharides and could be identified in extracts by $\mu$-HPLC-ESI-MS/MS.

\section{Conclusions}

In this work, an enzymatic treatment enhancing extractability of copper complexes from bilberry and açaí fruits was performed. It was demonstrated that $\mu$-HPLC-ESI-MS/MS is a great tool for identification of copper complexes with bioligands in extracts. The comparison of copper extracts after the enzymatic treatments of pectinase and hemicellulase was carried out for the first time by HPLC-ICP-MS and ESI-MS/ MS method. Additionally, the size exclusion method allowed separating main species which was helpful to confirm good stability of all species in extraction media.

The $\mu$-HPLC-ESI-MS/MS chromatograms, obtained in this study, show that extraction medium, pectinase, is responsible for extraction of different copper species from berries than ammonium acetate or hemicellulase. The pectinase breaks down the cell wall and releases the metal complexes from fruit skin and pulp. The enzymatic extraction helps in identification of copper complexes which are responsible for better bioavailability of copper for human bodies. 


\section{Compliance with Ethical Standards}

Conflict of Interest Lena Ruzik declares that she has no conflict of interest. Justyna Wojcieszek declares that she has no conflict of interest.

Ethical Approval This article does not contain any studies with human participants performed by any of the authors.

Informed Consent Not applicable.

Open Access This article is distributed under the terms of the Creative Commons Attribution 4.0 International License (http:// creativecommons.org/licenses/by/4.0/), which permits unrestricted use, distribution, and reproduction in any medium, provided you give appropriate credit to the original author(s) and the source, provide a link to the Creative Commons license, and indicate if changes were made.

\section{References}

Kalt W, Forney CF, Martin A, Prior RL (1999) Antioxidant capacity, vitamin $\mathrm{C}$, phenolics, and anthocyanins after fresh storage of small fruits. J Agric Food Chem 47:4638-4644

Kähkönen MP, Hopia AI, Heinonen M (2001) Berry phenolics and their antioxidant activity. J Agric Food Chem 49:4076-4082

Szajdek A, Borowska EJ (2008) Bioactive compounds and healthpromoting properties of berry fruits: a review. Plant Foods Hum Nutr 63:147-156

Wang SY, Lin HS (2000) Antioxidant activity in fruits and leaves of blackberry, raspberry, and strawberry varies with cultivar and developmental stage. J Agric Food Chem 48:140-146

Skupień K, Oszmiański J (2004) Comparison of six cultivars of strawberries (Fragaria ananassa Duch.) grown in Northwest Poland. Eur Food Res Technol 219:66-70

Strudwick J, Sobel GL (1988) Uses of Euterpe oleracea Mart. in the Amazon estuary. Adv Econom Bot 6:225-253

Heinrich M, Dhanji T, Casselman I (2011) Açai (Euterpe oleracea Mart.) - a phytochemical and pharmacological assessment of the species' health claims. Phytochem Lett 4:10-21

Rogez H, Pompeu DR, Akwie SNT, Larondelle Y (2011) Sigmoidal kinetics of anthocyanin accumulation during fruit ripening: a comparison between açai fruits (Euterpe oleracea) and other anthocyanin-rich fruits. J Food Compos Anal 24:796-800

Bichara CMG, Rogez H (2011) In: Yahia EM (ed) Postharvest Biology and Technology of Tropical and Subtropical Fruits. Woodhead Publishing Limited, Cambridge

Dias ALS, Rozet E, Chataigné G (2012) A rapid validated UHPLC-PDA method for anthocyanins quantification from Euterpe oleracea fruits. J Chromatogr B 907:108-116

Smith RE, Eaker J, Tran K (2012) Proposed benchmark methods for analyzing Açaí (Euterpe oleraceae Mart.). Nat Prod J 2:76-85

Pacheco-Palencia LA, Duncan CE, Talcott ST (2009) Phytochemical composition and thermal stability of two commercial açai species, Euterpe oleracea and Euterpe precatoria. Food Chem 115:1199_ 1205

Mulabagal V, Calderón AI (2012) Liquid chromatography/mass spectrometry based fingerprinting analysis and mass profiling of Euterpe oleracea (açaí) dietary supplement raw materials. Food Chem 134:1156-1164

Dias ALS, Rozet E, Larondelle Y, Hubert P, Rogez H, Quetin-Leclerc J (2013) Development and validation of an UHPLC-LTQ-Orbitrap
MS method for non-anthocyanin flavonoids quantification in Euterpe oleracea juice. Anal Bioanal Chem 405:9235-9249

Chu WK, Cheung SCM, Lau RAW (2011) In: Wachtel-Galor S, Benzie IFF (eds) Bilberry (Vaccinium myrtillus L.). CRC Press, Boca Raton (FL)

Dinkova R, Heffels P, Shikov V, Weber F, Schieber A, Mihalev K (2014) Effect of enzyme-assisted extraction on the chilled storage stability of bilberry (Vaccinium myrtillus L.) anthocyanins in skin extracts and freshly pressed juices. Food Res Int 65:35-41

Tumbas Šaponjac V, Čanadanović-Brunet J, Ćetković G, Djilas S, Četojević-Simin D (2015) Dried bilberry (Vaccinium myrtillus L.) extract fractions as antioxidants and cancer cell growth inhibitors. LWT - Food Sci Tech 61:615-621

Beattie J, Crozier A, Duthie G (2005) Potential health benefits of berries. Curr Nut Food Sci 1:71-86

Rouanet JM, Décordé K, Del Rio D, Auger C, Borges G, Cristol JP (2010) Berry juices, teas, antioxidants and the prevention of atherosclerosis in hamsters. Food Chem 118:266-271

Middleton E, Kandaswami C (1994) Harborne JB (ed) The Flavonoids: Advances in Research Since 1986, Chapman \& Hall, London

Malesev D, Kunti V (2007) Investigation of metal-flavonoid chelates and the determination of flavonoids via metal-flavonoid complexing reactions. J Serb Chem Soc 72:921-939

Symonowicz M, Kolanek M (2012) Flavonoids and their properties to form chelate complexes. Biotechnol Food Sci 76:35-41

Domínguez S, Torres J, Morales P, Heinzen H, Bertucci A, Kremer C (2008) In: Cartere TW, Verley KS (eds) Coordination Chemistry Research Progress, Nova Science Publishers, New York

Arnous A, Meyer AS (2008) Comparison of methods for compositional characterization of grape (Vitis vinifera L.) and apple (Malus domestica) skins. Food Bioprod Process 86:79-86

Arnous A, Meyer AS (2010) Discriminated release of phenolic substances from red wine grape skins (Vitis vinifera L.) by multicomponent enzymes treatment. Biochem Eng J 49:68-77

Hyun-Ku K, Jeong-Ryong D, Tae-Soo L, Kashif A, Sung-Ran Y, JoongHo K (2012) Optimisation of microwave-assisted extraction for functional properties of Vitis coignetiae extract by response surface methodology. J Sci Food Agric 92:1780-1785

Simsek M, Sumnu G, Sahin S (2012) Microwave assisted extraction of phenolic compounds from sour cherry pomace. Sep Sci Technol 47: $1248-1254$

Brahim M, Gambier F, Brosse N (2014) Optimization of polyphenols extraction from grape residues in water medium. Indust Crops Prod 52:18-22

Meyer AS, Jepsen SM, Srrrensen NS (1998) Enzymatic release of antioxidants for human low-density lipoprotein from grape pomace. J Agric Food Chem 46:2439-2446

Pawlak K, Lipiec E, Szpunar J (2012) In: Pawliszyn J, Le XC, Li XF, Lee HK (eds) Comprehensive Sampling and Sample Preparation. Elsevier, Academic Press, Oxford, UK

Arvayo-Enriquez H, Mondaca-Fernandez I, Gortarez-Moroyoqui P, Lopez-Cervantes J, Rodriguez-Ramirez R (2013) Carotenoids extraction and quantification: a review. Anal Met 5:2916-2924

Arnous A (2009) Enzymatic Release of Phenolics from Fruit Skins: With Grape as the Main Model. Ph.D. thesis, Technical University of Denmark

Laroze L, Soto C, Zúniga ME (2010) Phenolic antioxidants extraction from raspberry wastes assisted by-enzymes. Electronic J Biot 13, DOI: $10.2225 /$ vol13-issue6-fulltext-12

Shibuya N, Nakane R (1984) Pectic polysaccharides of rice endosperm cell walls. Phytochemistry 23:1425-1429

Buchert J, Koponen JM, Suutarinen M, Mustranta A, Lille M, Törrönen R (2005) Effect of enzyme-aided pressing on anthocyanin yield and profiles in bilberry and black currant juice. J Sci Food Agr 85:25482556 
Kaponen JM, Happonen AM, Auriola S, Kontkanen H, Buchert J, Poutanen KS (2008) Characterization and fate of black currant and bilberry flavonols in enzyme-aided processing. J Agr Food Chem 56:3136-3144

Wada M, Nishiyama Y, Chanzy H, Forsyth T, Langan P (2008) The structure of celluloses. ICDD 51:138-144

Nishiyama Y, Sugiyama J, Chanzy H, Langan P (2003) Crystal structure and hydrogen bonding system in cellulose I $\alpha$ from synchrotron X-ray and neutron fiber diffraction. J Am Chem Soc 125:14300-14306

Fernandez MT, Mira ML, Florencio MH, Jennings KR (2002) Iron and copper chelation by flavonoids: an electrospray mass spectrometry study. J Inorg Biochem 92:105-111

Rybak J, Ruzik L (2013) Application of chromatography and mass spectrometry to the characterization of cobalt, copper, manganese and molybdenum in Morinda Citrifolia. J Chromatogr A 1281:19-25

Howlett GJ, Minton AP, Rivas G (2006) Analytical ultracentrifugation for the study of protein association and assembly. Curr Op Chem Biol 10:430-436

Karasiński J, Cegiełkowska W, Wojciechowski M, Wierzbicka M, Bulska E (2014) Analytical protocol for investigation of zinc speciation in plant tissue. Chem Papers 68:291-299

Persson DP, Hansen TH, Laursen KH, Schjoerring JK, Husted S (2009) Simultaneous iron, zinc, sulfur and phosphorus speciation analysis of barley grain tissues using SEC-ICP-MS and IP-ICP-MS. Metallomics 1:418-426

Vacchina V, Połeć K, Szpunar J (1999) Speciation of cadmium in plant tissues by size-exclusion chromatography with ICP-MS detection. J Anal At Spectrom 14:1557-1566
Pinelo M, Arnous A, Meyer AS (2006) Upgrading of grape skins: significance of plant cell-wall structural components and extraction techniques for phenol release. Trends Food Sci Technol 17:579-590

Conn S, Zhang W, Franco C (2003) Anthocyanic vacuolar inclusions (AVIs) selectively bind acylated anthocyanins in Vitis vinifera L. (grapevine) suspension culture. Biotech Lett 25:835-839

Fry SC (1982) Phenolic components of the primary-cell wallferuloylated disaccharides of d-galactose and l-arabinose from spinach polysaccharide. Biochem J 203:493-504

Ishii T (1994) Feruloyl oligosaccharides from cell walls of suspension cultured spinach cells and sugar beet pulp. Plant Cell Physiol 35: 701-704

Joutei KA, Glories Y, Mercier M (1994) Localization of tannins in grape berry skins. Vitis 33:133-138

Sun J, Liang F, Bin Y, Li P, Duan C (2007) Screening non-colored phenolics in red wines using liquid chromatography/ultraviolet and mass spectrometry/mass spectrometry libraries. Molecules 12:679-693

Ríha M, Karlíckova J, Filipsky T, Macakova K, Rocha L, Bovicelli P, Silvestri IP, Saso L, Jahodar L, Hrdina R, Mladěnka P (2014) In vitro evaluation of copper-chelating properties of flavonoids. RSC Adv 4: 32628-32638

Mladenka P, Macakova K, Filipsky T, Zatloukalova L, Jahodar L, Bovicelli P, Silvestri IP, Hrdina R, Saso L (2011) In vitro analysis of iron chelating activity of flavonoids. J Inorg Biochem 105:693-701

Markham KR, Gould KS, Winefield CS, Mitchell KA, Bloor SJ, Boase MR (2000) Anthocyanic vacuolar inclusions - their nature and significance in flower colouration. Phytochemistry 55:327-336 